\title{
IfIISGUC.ORG
}

"İ̦̦, GÜC̣" ENDÜSTRi iLIȘKiLERi VE INSAN KAYNAKLARI DERGisi

"IS, GUC" INDUSTRIAL RELATIONS AND HUMAN RESOURCES JOURNAL

\section{Hamile Kadınların Çalışma Yaşamında Maruz Kaldığı Ayrımcı Uygulamalar}

Discriminatory Practices against Pregnant Women In Work Life

\section{Elif Tuğba DOĞAN}

Arş. Gör. Dr., Ankara Üniversitesi, SBF, Çalışma Ekonomisi ve

Endüstri İlişkileri Bölümü

Nisan/April 2012, Cilt/Vol: 14, Sayı/Num:2, Page: 79-98

ISSN: 1303-2860, DOI: 10.4026/1303-2860.2012.0200.x

Makalenin on-line kopyasına erişmek için:

http://www.isguc.org/?p=article\&id=490\&vol=14\&num=2\&year=2012

To reach the on-line copy of article:

http://www.isguc.org/? $\mathrm{p}=$ article\&id=490\&vol=14\&num=2\&year=2012

Makale İçin İletişim/Correspondence to: 
(c) 2000- 2012

“İşGüç” Endüstri İlişkileri ve İnsan Kaynakları Dergisi

"İşGüç" Industrial Relations and Human Resources Journal

\author{
Nisan/April 2012, Cilt/Vol: 14, Say1/Num: 2 \\ ISSN: 1303-2860, DOI: 10.4026/1303-2860.2012.0200.x
}

İş,Güç, Endüstri İlişkileri ve İnsan Kaynakları Dergisi, yılda dört kez yayınlanan hakemli, bilimsel elektronik dergidir. Çalışma hayatına ilişkin makalelere yer verilen derginin temel amacı, belirlenen alanda akademik gelişime ve paylaşıma katkıda bulunmaktadır.

İş, Güç, Endüstri İlişkileri ve İnsan Kaynakları Dergisi, 'Türkçe' ve 'İngilizce' olarak iki dilde makale yayınlanmaktadır. Dergi ulusal ve uluslar arası birçok indekste taranmaktadır. (CABELLS DIRECTORY, EBSCO SOCINDEX , INDEX ISLAMICUS, INDEX COPERNICUS, WORLDWIDE POLİTICAL SCIENCE ABSTRACTS, SOCIOLOGICAL ABSTRACT, ULAKBIM SOSYAL BİLIMLER VERİTANI, ASOS INDEX)

\section{Editör/Editor-in-Chief \\ Aşkın Keser (Uludağ University)}

Editör Yardimcıları/Co-Editors

K.Ahmet Sevimli (Uludağ University)

Gözde Yilmaz (Marmara University)

Uygulama/Design

Yusuf Budak (Kocaeli Universtiy)

\section{Tarandiğı Indeksler}

EBSCO SOCINDEX

Index ISLAMICUS

Index COPERNICUS

Worldwide Political Science

Abstracts

Sociological Abstract

ULAKBIM Sosyal Bilimler

Veritanı

CABELLS DIRECTORY

ASOS INDEX
Yayın Kurulu / Editorial Board

Dr. Erdem Cam (ÇASGEM)

Dr. Zerrin Firat (Uludağ University)

Doç. Dr. Aşkın Keser (Uludağ University)

Prof. Dr. Ahmet Selamoğlu (Kocaeli University)

Yrd. Doç. Dr. Ahmet Sevimli (Uludă̆ University)

Doç. Dr. Abdulkadir Șenkal (Kocaeli University)

Doç. Dr. Gözde Yilmaz (Marmara University)

Dr. Memet Zencirkıran (Uludă̆ University)

Uluslararası Danışma Kurulu / International Advisory Board Prof. Dr. Ronald Burke (York University - CA)

Assoc. Prof. Dr. Glenn Dawes (James Cook University - AU)

Prof. Dr. Jan Dul (Erasmus University - NL)

Prof. Dr. Alev Efendioğlu (University of San Francisco - USA)

Prof. Dr. Adrian Furnham (University College London - UK)

Prof. Dr. Alan Geare (University of Otago - NZ)

Prof. Dr. Ricky Griffin (TAMU-Texas A\&M University - USA)

Assoc. Prof. Dr. Diana Lipinskiene (Kaunos University - LT)

Prof. Dr. George Manning (Northern Kentucky University - USA)

Prof. Dr. William L. Murray (University of San Francisco - USA)

Prof. Dr. Mustafa Özbilgin (Brunel University - UK)

Assoc. Prof. Dr. Owen Stanley (James Cook University - AU)

Prof. Dr. Işık Urla Zeytinoğlu (McMaster University - CA)

Ulusal Danışma Kurulu / National Advisory Board

Prof. Dr. Yusuf Alper (Uludă̆ University)

Prof. Dr. Veysel Bozkurt (İstanbul University)

Prof. Dr. Toker Dereli (Işık University)

Prof. Dr. Nihat Erdoğmuş (Şehir University)

Doç. Dr. Mustafa Kurt (Yalova University)

Prof. Dr. Ahmet Makal (Ankara University)

Prof. Dr. Süleyman Özdemir (İstanbul University)

Prof. Dr. Ahmet Selamoğlu (Kocaeli University)

Prof. Dr. Nadir Suğur (Anadolu University)

Prof. Dr. Nursel Telman (Maltepe University)

Prof. Dr. Cavide Uyargil (İstanbul University)

Prof. Dr. Engin Yildirim (Constitutional Court of Turkey)

Doç. Dr. Arzu Wasti (Sabancı University)

Dergide yayınlanan yazılardaki görüşler ve bu konudaki sorumluluk yazarlarına aittir.

Yayınlanan eserlerde yer alan tüm içerik kaynak gösterilmeden kullanılamaz.

All the opinions written in articles are under responsibilities of the outhors.

The published contents in the articles cannot be used without being cited. 


\title{
Hamile Kadınların Çalışma Yaşamında Maruz Kaldığı Ayrımci Uygulamalar
}

\author{
Discriminatory Practices against Pregnant Women In Work Life
}

\author{
Elif Tuğba DOĞAN \\ Arş. Gör. Dr., Ankara Üniversitesi, SBF, Çalı̧̧ma Ekonomisi ve \\ Endüstri İlişkileri Bölümü
}

\begin{abstract}
Özet
Kadınların çalışma yaşamında, pek çok ayrımcı uygulamaya maruz kaldıkları bilinmektedir. Bu makalede de çalışma yaşamında cinsiyete dayah ayrımcilğ̆ın bir türü olarak, hamileliğe dayah ayrımcllık incelenmektedir. Günümüzde ulusal ve uluslararası pek çok belge ile hamileliğe dayalı ayrımcllık yasaklanmıştır. Ne var ki tüm yasal güvencelere rağmen, Türkiye'de ve dünyanın birçok yerinde kadınlar hamilelik nedeniyle işyerlerinde ayrımcılığa maruz kalmakta hatta bazı işyerlerinde hamile kalmaları yasaklanabilmektedir. Bu ayrımcı uygulamaların en çarpıcı örneklerine uluslararası işbölümünde ucuz işgücü olarak kadın emeği kullanan Latin Amerika ülkelerinin serbest bölgelerinde (maquilalarda), rastlanmaktadır. Çalışmanın amacı, ayrımcılık karşıtı ulusal ve uluslararası belge/düzenlemelere rağmen, kadınların çalışma yaşamında hamilelik nedeniyle karşı karşıya kaldıkları ayrımcı pratikleri örneklendirerek tartısmak ve kadın bedeni üzerindeki denetimin boyutlarma dikkat çekmektir. Bu amaçla, kadının doğurganlığı, doğum kontrol teknolojilerinin gelişimi, hamile kadının çalışma yaşamında varlığı ile ulusal ve uluslararası düzenlemelere rağmen uygulamadaki sorunlar çalışmada strayla ortaya konacaktır.
\end{abstract}

Anahtar Kelimeler: Doğurganlık, doğum kontrolü, hamileliğe karşı ayrımcıllk, maquiladora, toplumsal cinsiyet, kadın işgücü

\begin{abstract}
It is known that women are exposed to discrimination in their work life. In this study, the pregnancy discrimination as a kind of gender discrimination in the work life is investigated. Nowadays, many national and international documents prohibit pregnancy discrimination. Nevertheless, despite the presence of all legal assurance, the pregnancy discrimination does exist in the work places; even getting pregnant can be forbidden. The most striking examples of this discrimination can be found in the countries of Latin America, in the free trade zones - in maquilas, where female labor is used as cheap workforce in international division of labor. The aim of this study is to discuss the discriminating actions based on pregnancy in work places within the examples, in spite of the existence of national and international documents/regulations against discrimination; and to draw attention to the magnitude of supervision on women body. To do so, women fertility, the development of contraception methods, the presence of pregnant women in the work life and the problems regardless of the national and international regulations are examined respectively.
\end{abstract}

Key words: Fertility, contraception, pregnancy discrimination, maquiladora, gender, female labor force 


\section{GiRiş}

Kadının çalışma yaşamında karşılaştığı pek çok sorun vardır. İşe giriş aşamasında başlayan sorunlar, işe girdikten sonra da devam etmektedir. Kadının yaşadığı toplumda sahip olduğu toplumsal ve kültürel anlamlar, onun biyolojik nitelikleriyle de şekillenmektedir. Biyolojik niteliği nedeniyle karşılaştığ1 sorunların başında kadının doğurganlığ1 ve hamile kalması gelmektedir. Hamilelik ve doğum sonrası analık halleri, kadının toplumsal ve ekonomik ilişkilerini farklı yönlerde etkilemektedir. Cinsiyete dayalı işbölümü içinde kadının ev içindeki yeniden üretim faaliyetleri kadına erkeğe kıyasla daha fazla sorumluluk yüklemektedir. Temel roller olarak kadına atfedilen eş ve annelik, kadının ev içindeki sorumluluklarını da belirlemektedir. Ev dışında ücretli çalışmanın ikincil olarak değerlendirildiğ $i$ durumlarda, çalışma yaşamına katılan kad1nın bu kez hamileliği ve anneliği kadının omuzlarındaki yükü artırmaktadır.

Kadın doğurganlığ 1 bireysel olduğu kadar toplumsal bir olgudur. Kadının kendi bedeniyle ilgili bireysel kararları sosyo-ekonomik, siyasal etkenlerden tümüyle bağımsız değildir. Özellikle ücretli bir işte çalışan kadınların doğurganlığı, kendisini, yakın çevresini, işverenini ve devleti ilgilendirmektedir. Örneğin devlet, nüfus politikaları yoluyla kadının doğurganlığına müdahil olduğu gibi çalışma yaşamında da bu konuya yasal düzenlemeler ve uygulamalar yoluyla müdahale etmektedir. Doğal olarak bu yaklaşım uyarınca iş yerlerinde hamile kadınlara işverenin de müdahalesi söz konusu olmaktadır. Bu nedenle makalede kadının doğurganlığ 1 üzerindeki denetim mekanizmalarından söz edilmektedir. Bu çalışma, ücretli bir işte çalışan kadınların doğurganlığı ve hamilelikle bağlantılı işyeri denetimiyle sınırlandırılmıştır.

Gelişmiş ve gelişmekte olan pek çok ülkede kadın çalışanlar, ulusal ve uluslararası koruyucu yasal düzenlemelere rağmen, hamilelikleri nedeniyle ayrımcı uygulamalara maruz kalmaktadır. İşverenler açısından ha- mile çalışan doğum öncesi ve sonrası aldığ 1 izinlerle maliyet kaynağı olarak görülmektedir. Yasal düzenlemelerle korunan bu ücretli izin, işverenin üretim faaliyetlerini etkilediği için işyerlerinde hamile çalıșanlara talebi, gelişmiş ülkelerde dahi sınırlandırmaktadır. Bu durum esasen kadın işgücüne talebi etkilemesi açısından da önemlidir. Toksöz (2011b: 27), kadın işgücüne talebin sinırlı olmasının nedeni olarak, kadınların hamilelik gibi yeniden üretim faaliyetlerinin işgücü maliyetlerinin artışını göstermekte ve işverenlerin bu maliyetlere katlanmaya gönüllü olmadığını ifade etmektedir. Hamile çalışanlara karşı olumsuz yaklaşımlar, bizim çalışmamızın da odağında yer almaktadır.

Kuşkusuz doğum kontrol teknolojilerinin XX. yüzyılda gelişimi, kadının kendi doğurganlığını sağlıklı biçimde kontrol edebilmesine olanak sağlamıştır. Aynı zamanda bu teknolojiler arzu edilir çocuk sayısı ile zaman ve enerji bakımından iş yükünü azaltarak kadının istihdama katılımını artırıcı etki yaratmıştır. Ancak bu konuda mevcut uygulamaların olumlu ve olumsuz sonuçlarını içeren geniş bir tartışma alanı da bulunmaktadır. Bu çalışmada öncelikle kadının doğurganlığının toplumsal, ekonomik ve politik alanlardaki anlamlarina yer verilecek, ardından doğurganlığın denetimi tartışılacaktır. Ayrıca çalışmada artan kadın istihdamıyla çalışma yaşamında karşılaşılan sorunlara ilişkin yasal düzenlemelere sınırlı biçimde yer verilerek, koruyucu yasal düzenlemelere rağmen karşılașılan sorunlar, örnekler üzerinden değerlendirilecektir.

Günümüzde değişen uluslararası işbölümü, azgelişmiş ve gelişmekte olan ülkelerin ham madde ihraç eden geleneksel niteliğine yenilerini eklemiștir. Buna göre anılan ülkeler ucuz işgücü "olanakları" ile gelişmiş ülkeler adına üretimden de sorumlu olmaya başlamıştır. Özellikle kadın emeği burada ucuz işgücünün kaynağ1 olarak değerlendirilmekte ancak doğurganlık özellikleri ucuz ve verimli işgücü olma vasıflarını dönemsel olarak yitirmelerine neden olmaktadır. Çalışmada, uluslararası 
işbölümü içinde ihracata dayalı kalkınma hedeflerini gerçekleştirmede yoğun biçimde ucuz kadın emeği kullanan serbest bölgeler -Latin Amerika örneğinde maquilalar- hamileliğin büyük bir sorun olarak değerlendirildiği yerler olarak değerlendirilecektir.

\section{Kadının Yeniden Üretim Faaliyetleri İçinde Doğurganlık ve Doğurganlığın Denetimi}

Kadının doğurganlığı, yalnızca kendisini ve yakın çevresini değil aynı zamanda toplumu ve ülkenin gelecek nüfusunu da ilgilendiren bir konu olarak, mikro ve makro ölçekte değerlendirilebilir. Mikro ölçekte dogurganlığın denetimi aile planlaması olarak ifade edilirken, makro ölçekte konu nüfus planlaması kapsamındadır. Gerek mikro ölçekte aile planlaması biçiminde olsun, gerekse makro ölçekte nüfus planlaması biçiminde olsun; doğurganlığın "hane" ya da "devletçe" kontrol altında tutulabilmesi, kadın bedeni üzerinde farklı baskı/tahakküm biçimlerine olanak tanıyabilmektedir. Doğum kontrolü alanında gözlenen teknolojik ilerleme, çelişkili bir şekilde, kadını özgürleştirici bir etki yarattığı gibi, aynı zamanda devletin, kocanın ya da sermayenin kadınların doğurganlığı üzerindeki denetimini ya da denetim olanaklarını da artırabilmektedir. Çünkü kadının kendi bedenine yönelik bireysel karar alma süreci, içinde yer aldığ 1 sosyo-ekonomik çevreden bağımsız gerçekleşememekte, bu kararı etkileyen ekonomik, siyasal, toplumsal, kültürel ve biyolojik faktörlerle süreç tamamlanmaktadır. Özellikle kadının doğurganlık vasfına ilişkin tıbbi müdahale olanaklarının artmasıyla, doğurganlığın farklı tekniklerle kontrol altına alındığı günümüzde, kadının kendi bedeni hakkındaki karar süreçlerine farklı aktörlerin farklı çerçevelerde müdahalesi olanaklı hale gelmiştir. Bu yönüyle, kadının kendi bedeni üzerindeki kontrolünün bir aracı olma işlevini üstlenebilecek bir teknolojik gelişme olan doğum kontrolü, tersine kadının kendi bedeni üzerindeki söz söyleme/belirleme yetkisinin, farklı aktörlere (devlete, haneye, işverene) transferi anlamına gelebilmektedir. Bu aktörler ise ekonomik, sosyal, kültürel araçlarla kadının doğurganlığını hem zamanlama (ne zaman hamile kalacak) hem de nicelik (kaç çocuk doğuracak) açısından belirleyebilmektedir. Özellikle doğum kontrol teknolojilerinin gelişimi ve doğurganlığ1 kontrol altına almaya yönelik kadına ve erkeğe yönelik farklı tekniklerin gelişmesi, bireyin kararlarını etkileme kapasitesine sahip farklı toplumsal kurumların karar süreçlerindeki etkisini artırmaktadır. Üstelik bireyin kararları üzerinde etkili olabilecek toplumsal kurumların çeşitliliği, konuya çok katmanlı bir nitelik kazandırmaktadır. Bu noktada özel olarak belirtilmesi gereken bir konu da kadının doğurganlığı olup olmadığının ayrı bir sorun alanı olarak ortaya çıkmasıdır. Sunulan çalışmada odak nokta, kadının çalışma yaşamı içinde hamile kalması durumunda karşılaşılan sorunlar ile sınirlandırılmıştır.

Kadın doğurganlı̆̆ bölümünde kadının birincil görevinin eş ve anne olarak tanımlanışında etkilidir. Bu bağlamda kadın, işgücü piyasasındaki üretici konumundan ziyade hane içinde doğurganlığ1 ile yeniden üretimden sorumlu tutulmaktadır. Bu sorumluluk, yüzyıllardır kadının ilk görevinin eşi ve çocukları için çalışmak olduğunu topluma hatırlatmaktadır. Doğum yapmak ve yenidoğanın bakımını üstlenmek, doğadaki pek çok canlıda da anne tarafından üstlenilen bir görevdir. Bu anlamda biyolojik bir yanı olduğu yadsınamasa da annelik rolü kurgusunun kültürel bir nitelik taşıdığı da belirtilmelidir.

Annelik, zamana ve mekâna göre farklı biçimlerde tanımlanmakta ve algılanmaktadır. Örneğin Fransa'da 1990'l1 y1llarda ekonomik bunalım ve kitlesel işsizlik sorunları yaşanırken kadınların işgücü piyasasının d1şında kaldıkları durumda anneliğin tekrar ön plana çıkarıldığı görülmektedir (Badinter, 2011: 10). Anneliğin kutsallığ1 ve içgüdüsel temeli de yine farklı kültürlerde farklı algılanmakta ve tartışılmaktadır. Bu konuda toplumların homojen bir tutuma sahip ol- 
duklarını söylemek güçtür. Örneğin Bangladeş'te doğum kirli bir olay olarak değerlendirilerek ebelik kurumu gelişmemişken, doğurganlığın yüceltildiği Polinezya'da yetenekli ebelerden söz etmek mümkündür (Emiroğlu ve Aydın, 2003:237). Badinter (2011: 26- 34) de Güney Avrupa ile Kuzey Avrupa arasında anneliğe bakışın farklılık gösterebildiğinden söz etmektedir.

Feminist düşünceler kapsaminda ise anneliğe atfedilen farklı değerler vardır. Örneğin Simone de Beauvoir, anneliği kadın üzerinde baskı kaynağ1 olarak görmüştür. Buna 1980'lerin başında bir grup feminist anneliği daha insani bir dünyanın temellerini atmada etkili, önemli bir kadınlık deneyimi olarak kavramlaştırmıştır (Badinter, 2011: 61). Annelik kadar anne olamama hali de bireysel ve toplumsal bir sorun olarak karşımıza çıkmaktadır. Kısırlık, kadın üzerinde toplumun anneliğe ve doğurganlığa verdiği değerle bağlantılı olarak bir baskı nedeni olabilmektedir. Kısırlığın kadın üzerindeki toplumsal ve psikolojik etkilerini, bu süreci deneyimleyen kadınların bakış açısıyla sorgulayan Akşit'in (2009) çalışmasında da görüleceği gibi, kadının doğurganlığına ilişkin algı sınıfsal farklılıklardan da etkilenmektedir.

Kadının doğurganlığına ilişkin değerlendirmeler, ne ekonomik sistemden ne de kültürden bağımsızdır. Kadının hane içinde çocuk doğurma ve bakım hizmetleri gibi yeniden üretim faaliyetleri, hanedeki erkeğe olduğu kadar kapitalist ekonomiye de yarar sağlamaktadır (Toksöz, 2011a: 109). Bilindiği gibi, tarım toplumlarında çocuğun işgücüne katılımı, sanayileşmiş toplumlara oranla daha fazladır. Çocuklar, kırsal alanda hane halkına üretimde destek olurlarken, kentsel alanlarda hane halkı açısından tüketici konumdadırlar. Bu da çocuk sayısını kentsel alanda, daha geniş ifade ile sanayi toplumlarında sinırlamaktadır. Yeniden üretim sürecinin biyolojik boyutu olarak çocuk doğurma, üretim ve işgücü ihtiyacıyla bağlantılı olarak değerlendirilmektedir. Dolay1sıyla kadının doğurganlığı ve sahip olduğu çocuk sayısı yalnızca kadını değil, haneyi ve toplumu da ilgilendirmektedir. Denebilir ki, ekonomik sistem kadın doğurganlığına da diğer yeniden üretim faaliyetlerine de ihtiyaç duymaktadır.

Ekonomik sistemlerin ihtiyaç duyduğu yeniden üretim faaliyetlerinin ve bizim çalışmamız açısından kadının doğurganlığının önemi, konuya devletin ve toplumların müdahil olmasinı da beraberinde getirmektedir. Bu müdahil olma durumu, kimi zaman doğurganlığın sınırlandırılması şeklinde olabilirken kimi zaman da tersine kadınlara daha çok çocuk doğurmalarını önererek, doğum kontrol yöntemlerinin kullanımı sınırland1rarak ya da gebeliğin istenmediği durumlarda kürtaj olmayı yasaklayarak gerçekleșebilmektedir. XVIII. yüzyılın sonlarından itibaren Malthus'la birlikte nüfus sayımlarının devletin düzenli işlemlerinden biri haline geldiği görülmektedir (Toksöz, 2011a: 121). Devlet, nüfusa ilişkin kayıtlarla nüfusun kontrolüne ilişkin politikaları da uygulamaktadır. Nüfus politikaları ile yukarıda da değinildiği gibi doğurganlık istenen seviyeye göre sinırlanabilmekte ya da teşvik edilmektedir.

XX. yüzyılda II. Dünya Savaşı nedeniyle erkek işgücünün sınırlı kaldığı durumlarda kadın, işgücü piyasasına tarım dışı alanlarda da girmeye başlamıştır. Yine de bu katılımin çok yüksek oranlarda gerçekleştiğini söylemek mümkün değildir (Toksöz, 2011b:23). $\mathrm{Bu}$ süreçte, nüfus politikaları da ülkelerin gündeminde yer almış, hem bireysel olarak kadının doğurganlığ 1 hem de toplumsal olarak nüfusun kontrol altına alınması gerekliliği yeniden tartışılmaya başlanmıştır. Kadınlar için uygun doğum kontrol teknolojilerinin gelişmesindeki ivme de iște bu dönemde kendini göstermiştir. Doğum kontrol teknolojilerinin gelişiminin beklenen ve beklenmeyen iki önemli etkisinden söz etmek mümkündür. Beklenen etki, nüfus kontrolü iken, beklenmeyen etki kadının kendi doğurganlığ 1 üzerindeki denetimi ile özellikle $X X$. yüzyılın son çeyreğinde hatırı sayılır bir güç kazanan kadın hareketi üzerinde ken- 
dini göstermiştir.

Sözü edilen teknolojik gelişmeler, kadının özgürleşmesinde etkili görünmekle beraber paradoksal biçimde kadını denetlemeye de aracı olmuştur. Literatürde "kadının özgürleşmesi" ev dişında emeğini sunmasıyla bağlantılı olarak da kullanılmaktadır. Kadınların istihdama artan katılımıyla gelir getirici çalışmanın kadını özgürleştiği tezinin, ödenen çalışmanın, kadının ödenmeyen çalışmasından üstün olduğu, kadınların kazandıkları ücreti kontrol ettiği, istihdam aracılığıyla elde edilen avantajların ev içi işbölümü ya da politik karar alma mekanizmalarında kontrolü artırdığı önermelerine dayandığ 1 düşüncesi tartışmalı bulunmaktadır (Toksöz, 2011a: 103-104).

\section{Doğum Kontrol Teknolojilerinin Gelişimi}

Görüldüğü gibi kadının doğurganlığının mikro ve makro düzeyde anlamları vardır. Ayrıca bu farklı yaklaşımların kadın doğurganlığının kontrolü ve teknolojinin kullanımı açısından da farklı sonuçları olması muhtemeldir. Doğum kontrolü, istenmeyen gebeliklerin önlenmesine yönelik bir denetim biçimidir ve aynı zamanda çiftin istediğ zaman, istediği kadar çocuk sahibi olmasını da kapsar. Doğum kontrolünün, aile planlaması olarak nitelendirilmesi ise daha çok ataerkil bir bakışın sonucudur. Kadının aile kurumu olmaksızın çocuk sahibi olmasını dışlayan anlayış, planlanan sürecin aileye ilişkin olduğu kabulüne dayanmaktadır.

Basalla (1996), teknolojinin kültürel bir evrimle geliştiğini iddia etmektedir. İnsan, doğa ile baş etmede çözüm olarak teknolojiyi kullanir. Bu anlamda teknoloji, insanın doğaya karşı mücadelesinde kültürel bir araç niteliğine bürünmektedir. Ancak teknolojinin geçmişten günümüze ilerlemesini doğal bir süreç olarak değerlendirmek hatalı olabilir. Çünkü teknoloji nötr olmadığı gibi, sermayenin, devletin ve bireylerin manipülasyonuna da açıtır. Dolayısıyla teknoloji kurgulanmış bir yapı olarak karşımıza çıkmaktadır (MacKenzie ve Wajcman, 1985) ve bu kurgulanmış yapı içinde doğum kontrol teknolojilerinin de kurgulanabilmesi de mümkündür. Genel olarak teknoloji, özel olarak da doğum kontrol teknolojileri toplumun ihtiyaçları doğrultusunda şekillendirilmektedir. Ekofeministler, teknolojinin eril nitelik taşıdığını, kadınla birlikte doğayı denetim altına almada ataerkil sistemin araçlarından biri olduğunu iddia etmektedirler (Savc1, 1999: 133). Özel olarak doğum kontrol teknolojileri de bu anlamda yine kadın bedeninin denetiminde eril nitelik taşıyabilmektedir.

Doğum kontrol teknolojileri, toplumsal denetimin bir aracı olarak müthiş bir potansiyele sahiptir (Morsy, 1997: 166). Sahip olduğu potansiyel ile sadece kadının değil, erkeğin, devletin ve sermayenin de taraf olduğu bir alandır doğum kontrol teknolojileri. Gerçekten içinde yaşadığımız dönem, kadın bedenine bilimsel ve tıbbi müdahalenin arttığ 1 bir süreci ifade etmektedir (Hanmer,1993: 243). Bu anlamda doğum kontrol teknolojilerinin kadını özgürleştirdiği argümanı kadının ev dışında ücretli çalışmasının kadını özgürleştirdiği argümanı ile benzerlik taşımaktadır. Ne var ki teknolojinin gelişimi kadını doğrudan özgürleştirmeye yetmemektedir. Teknoloji kadının kendi bedeni üzerinde kontrolünü sağlamada etkili olabildiği gibi kadının bedenini tahakküm altına almada da önemli bir araç olarak işlev görmektedir. Kadın doğum kontrol hapını kendi özgür iradesiyle kullandığında özgürleşirken, iş sürecinin kesintiye uğramaması beklentisi içindeki işverenin baskısına maruz kaldığında bu özgürlük söz konusu olmayacaktır.

Teknoloji geliştikçe aile ve nüfus planlamaları için kullanılan yöntemler günümüzde çeşitlilik kazanmıştır. 1960 yılında ABD'de Enovid adlı ilk doğum kontrol hapının kullanılması kadınlara çocuk doğurma ve kariyer planlarını yapmada görülmemiş bir özgürlük sunmuştur (Bailey, 2006: 289). Doğum kontrol hapları, kontrolü erkekten kadına transfer etmekte ve kontrolü erkeğin sorumlu olduğu bir süreç olmaktan çıkmaktadır. Ayrıca kadının erkeğin bilgisi olmak- 
sızın da kendi bedenini denetleyebilmesine imkân sunmaktadır. Tüm bunların sonucu olarak kadınlar ücretli bir işe girebilmişlerdir (Bailey, 2006: 295-296). Her ne kadar iktisatçılar savaş sonrası kadın emek arzının şekillenmesinde doğum kontrolüne itibar etmemişlerse de çalışmalar kadınların gerçek ücretlerinde bir artışı işaret etmektedir (Bailey, 2006: 317).

Doğum kontrol teknolojilerinin gelişimi ile kadın istihdamı arasında sıkı bir ilişkinin varlığ 1 bilinmektedir. Öncelikle, cinsiyetçi işbölümünün bir sonucu olarak hane içerisinde, çocuk ve yaşlı bakımı, yemeklerin hazırlanması vb. işlerin kadınlar tarafından üstlenilmesi, kadınların işgücüne katılımları üzerinde olumsuz etki yaratabilmektedir. Özellikle çocukların bakımına yönelik kreş vb kamusal hizmetlerin sinırlı olduğu ülkelerde, piyasadan sağlanan çocuk bakım hizmetlerinin yüksek maliyeti de kadınların işgücüne katılımını azaltmaktadır. Nitekim işgücü piyasası üzerine yapılan çalışmalar, kadınların işgücü piyasasına katılma kararında, evli olmalarının ve çocuk sahibi olmalarının da etkili olduğunu göstermektedir (Özşuca, 2003: 46). Bu yönüyle doğum kontrolü, kadınların işgücü arzını artırabilen bir unsur olarak karşımıza çıkmaktadır. Diğer taraftan kadının ev dışında işgücü piyasasında emeğini sunması, hamilelik kararlarını almasında da etkili olmaktadır (Mohapatra ve Roy, 2010; Boushey, 2008; Bailey, 2006). Ayrıca, hamilelik, kadının işgücü piyasasından geçici olarak çıkmasının yanı sıra tümüyle bu alandan çekilmesi anlamına da gelebilmektedir. $\mathrm{O}$ halde ev içinde yeniden üretim faaliyeti olarak gereksinim duyulan hatta belli devlet politikaları ile sınırlandır1lan ya da teşvik edilen çocuk doğurma, görüldüğü gibi kadının işgücü piyasasındaki varlığını etkileme gücüne sahiptir.

Öte yandan, kadın işgücü piyasasına katılsa da emeği, günümüzde hâlâ cinsiyete dayalı işbölümü nedeniyle ikincil bir role sahiptir. Kadın, öncelikle eş ve anne olarak konumlandırılmakta, erkek ise üretimin örgütlenmesiyle ilişkilendirilmektedir. İşgücü içinde kadının işi bile (hemşirelik, öğretmenlik, sekreterlik, vb.) onun aile içindeki eş ve anne rolüyle ya da kişiliğiyle uyumlu olmaya meyillidir (Chodorow, 1999: 178180).

Kalkınma ve ekonomik gelişim gibi amaçlara ulaşma yolunda aile planlaması olarak adlandırılan denetim, daha genişletilmiş bir nüfus planlamasının da parçasıdır. Üstelik nüfus planlaması sadece bir devleti değil dünyanın genelini ilgilendiren bir olgu olarak karşımıza çıkmaktadır. Buna bağlı olarak demografi bilimi oluşmuş, nüfus etütleri ile konu ulusal olma niteliğine uluslararası bir boyut da katmıştır. Birleşmiş Milletler Nüfus Fonu (UNFPA) bu alanda çalışmalar yürüten uluslararası nitelikteki örgütlerden biri olarak, "her kadının, erkeğin ve gencin sağlıklı ve eşit bir hayat sürdürmesi için çalışmaktadır. UNFPA devletleri yoksulluğu azaltma politikaları geliştirme sürecinde nüfus verilerinin kullanılması için desteklemekte, her hamileliğin istenilen, her doğumun güvenli ve her gencin HIV/AIDS'den korunmuş olması için faaliyet göstermekte, kadınların ve genç kızların hak ettiği saygılı muameleyi görmesi için destek vermektedir."1

\section{2. Çalışma Yaşamında Hamile Kadınlar İçin Koruyucu Yasal Düzenlemeler}

Çalışma yaşamında ulusal ve uluslararası düzenlemelerle cinsiyet eşitliği sağlanmaya çalışılmaktadır. Endüstri Devrimi ile birlikte hızla dönüşen yeni toplumsal ve ekonomik yaşamın modern öncesi dönemden farklı yapısı çalışma yaşamı içinde farklı düzenlemelere olan ihtiyacı da gündeme getirmiştir. Düşük ücretler, uzun çalışma saatleri, kadın ve çocukların gece vardiyalarında çalışmaları, kötü işyeri koşulları gibi olumsuzluklar ve bu olumsuzluklara karşı işgücünün mücadelesi günümüze gelene kadar ulusal ve uluslararası düzeyde pek çok hakkın tanınmasında etkili olmuştur.

Ücretli çalışmanın, ailenin geçiminden so- 
rumlu olarak görülen erkeğe özgü bir çalışma biçimi olarak tanımlanması, ilk düzenlemelerde açık ifadelerle olmasa da erkekleri muhatap almış gibidir. Ancak, özellikle XX. yüzyılda bu durum değişmiş, kadınlar da hak mücadelesiyle önemli kazanımlar elde edebilmişlerdir. 1970'li yıllarda Birleşmiş Milletler'in düzenlediği toplantı, konferans ve görüşmeler ışığında ortaya konan metinler günümüze gelene kadar dünya üzerinde pek çok ülkede yasal mevzuatın toplumsal cinsiyete duyarlı biçimde düzenlenmesinde temel bir rol üstlenmişlerdir. Birleşmiş Milletler, bağlı kuruluşları ve diğer bölgesel örgütlerin tavsiye kararları, düzenlemeleri elbette yukarıdan aşağıya verilen/ tanınan haklar olarak değerlendirilmemelidir. Kadınların kalkınma sürecinde ve politik alanda seslerini duyurmaları, anılan dönemde kadın hareketinin gücüyle ilişkilendirilebilir. Dolayısıyla hakların tanınmasında kadın hareketinin gücü asla yadsinmamalidir.

1975 yılının "Uluslararası Kadın Yılı" olarak Birleşmiş Milletler tarafından ilan edilmesi dünya kamuoyunun dikkatini kadın konusuna çekmeyi amaçlamıştır. Aynı yıl Meksika'da gerçekleştirilen I. Kadın Konferansı'nda "Eşit Haklar, Kalkınma ve Barış için Kadın On Yılı"nın ilan edilmesi ile akademik, siyasal ve toplumsal alanda toplumsal cinsiyet gündemde yer alabilmiştir. Kadın erkek eşitliği konusunda bu dönemde gerçekleştirilen başlica toplantılar şu şekilde siralanabilir (Ertürk, 2008):

- BM I. Dünya Kadın Konferansı (Meksiko 1975),

- BM II. Dünya Kadın Konferansı (Kopenhag 1980),

- BM III. Dünya Kadın Konferansı (Nairobi 1985),

- Rio, Kahire ve Viyana Konferansları (1990'lar),

- BM II. Dünya İnsan Hakları Konferansı (Viyana 1993),
- BM IV. Dünya Kadın Konferansı (Pekin 1995),

- Pekin +5

Anılan bu toplantılar kadın erkek eşitliği açısından önemli etkinlikler olarak görülmektedir. Bu süreç içinde, konumuz açısından önemli olan düzenleme, 1979 yılında onay ve katılıma açılan BM Kadınlara Karşı Her Türlü Ayrımcılığın Önlenmesi Sözleşmesi'dir (CEDAW). 1991 yılında yürürlüğe giren CEDAW, Türkiye tarafından da 1985 y1lında onaylanmıştır (Ertürk, 2008: 52). Sözleşmenin 1. maddesinde "kadınlara karş1 ayrım deyimi(nin) kadınların medeni durumlarına bakılmaksızın ve kadın ile erkek eşitliğine dayalı olarak politik, ekonomik, sosyal, kültürel, medeni ve diğer alanlardaki insan hakları ve temel özgürlüklerinin taninmasinı, kullanilmasinı ve bunlardan yararlanılmasinı engelleyen veya ortadan kaldıran veya bunu amaçlayan ve cinsivete bağlı olarak yapılan herhangi bir ayrım, mahrumiyet veya kisitlama anlaminda" 2 olacağı belirtilmiştir. Madde 11, evlilik ve analık sebebiyle kadınlara karşı olan ayrımı önlemek ve etkin çalışma hakkını sağlamak amaciyla, Taraf Devletlerin uygun önlemleri almaları konusunda yükümlülük getirmektedir.

Uluslararası Çalışma Örgütü (ILO) sözleşmeleri de yine çalışma yaşamında kad1nın hamilelik nedeniyle uğrayabileceği ayrımcılığa ilişkin düzenlemeler yapmıştır. ILO sözleşmeleri içinde, 156 sayılı Ailevi Sorumlulukları Haiz Çalışanlar Sözleşmesi, 183 sayılı Analığın Korunması Sözleşmesi, 89 sayılı Yeniden Gözden Geçirilmiş Gece Çalışması (Kadın) Sözleşmesi, 171 sayılı Gece Çalışması Sözleşmesi ve158 sayılı Hizmet İlişkisine İşveren Tarafından Son Verilmesi Hakkında Sözleşme, hamile kadınların çalışmalarını düzenleyen hükümler içermektedir. Buna göre, hamilelik, doğum izni nedeniyle işe gelmeme, işe son verme için geçerli bir neden teşkil etmemektedir. Türkiye sayılan bu sözleşmelerden sadece 158 sayılı sözleşmeyi imzalamıştır. 
Benzer şekilde Avrupa Birliği mevzuatı içinde de, kadın erkek eşitliğine dair düzenlemelere gidilmiş, topluluk direktiflerinde eşitliğe yer verilmiştir. Direktiflerin yanı sıra çerçeve programlarda da düzenlemeler mevcuttur. Pek çok düzenleme içinden aşağ1da özellikle hamilelikle ilgili olan iki direktif sıralanmıştır:

- Tarım Dâhil, Kendi Nam ve Hesabına Çalışan Kadın ve Erkekler Arasında Eşit Muamele İlkesinin Uygulanması ve Kendi Nam ve Hesabına Çalışan Kadınların Hamilelik ve Analık Süresince Korunması Hakkında 11 Aralık 1986 tarih ve 86/613/EEC sayılı konsey direktifi ve

- Hamile, Loğusa veya Emzikli Çalışanların İş Sağlığı ve Güvenliğini Geliştirmeyi Teşvik Eden Önlemlerin Geliștirilmesine İlișkin 19 Ocak 1992 tarih ve 92/85/EEC sayılı konsey direktifi.

Türkiye onayladığı ILO sözleşmeleri ve 1985 yılında onayladığı Kadınlara Karşı Her Türlü Ayrımcılığın Önlenmesi Sözleşmesi (CEDAW) hükümleri ile iç mevzuatını uyumlu hale getirmek üzere çeşitli düzenlemelere gitmektedir. Bu çerçevede, 2003 y1lında 1475 sayılı İş Kanunu'nun yerini alan 4857 sayılı İş Kanunu yürürlüğe girmiştir. Yeni yasa ile kadın erkek eşitliği ve kadını koruyucu hükümler yeniden düzenlenmiştir. Yasanın 18. maddesinde hamilelik ve doğumun fesih için geçerli bir sebep olmadığ belirtilmiştir. Ayrıca, hamilelik süresince kadın işçiye periyodik kontroller için ücretli izin verilmektedir (md. 74).

Görüldüğü üzere, çalışma yaşaminda kadın erkek eşitliğine dair düzenlemeler, kadınları çalışma yaşamında karşılaşabilecekleri ayrımcı uygulamalara karșı koruma amacındadır. Bu ayrımcı uygulamaların bir türü de şüphesiz hamilelere karşı ayrımc1lıktır. Hamilelik ve doğum kadınları etkileyen olaylar olduklarından, anılan nedenlere dayalı olarak yapilan ayrımcılık, cinsiyete dayalı ayrımcılık kapsamında değerlendiril- mektedir (Yıldız, 2008: 89). Değinilen toplantılar ve düzenlemelerin ortak niteliği, hamilelik süresince ve doğumdan sonra kadın çalışanları korumak ve ayrımcı muameleleri yasaklamayı hedeflemeleridir. Yapılacak işin konusu ve niteliği gereği işverenin adaya hamile olup olmadığını sorması haklilaştırılabilirken (Yıldiz, 2008: 199), işin niteliğ $i$ kadın çalışanın hamileliğ $i$ ile değişmiyorsa burada ayrımcılıktan söz edilebilecektir (Ertürk, 2008: 157).

ABD'de üreme çağındaki kadınların bazı işlerde çalışmalarını engelleyen hükümlerle, kadınların doğmamış çocuklarını koruma düşüncesiyle getirilen yasaklar mevcuttur. $\mathrm{Bu}$ yasaklara rağmen yasa, ne mahkemelere ne de işverene kadın işçi adına, üreme sağlığ1 konusunda karar verme yetkisi tan1maktadır (Yıldız, 2008: 269). Daha önce de vurgulandığ1 gibi kadının doğurganlığı üzerinde kadından başka denetim güçleri de bulunmaktadır. Bu yasalarla mahkemeye ya da işverene yetki verilmese de uygulamada işverenlerin kadınların üreme sağlığ 1 ve doğurganlığı üzerinde etkili olması muhtemeldir. İzleyen bölümde, uygulamada karşılaşılan sorunlara örnekler verilecektir. $\mathrm{Bu}$ örnekler, yasaların ve düzenlemelerin kimi zaman niçin işleyemediğine dair bir bakış açısı sunacaktır.

\section{Hamile Kadınların Yasal Düzenlemelere Rağmen Çalışma Yaşamında Karşılaştığı Sorunlar: Örnekler}

Doğum kontrol teknolojilerinin gelişimi ile kadının ev dışında istihdamı arasındaki ilişki açıktır. Bu bölümde kadının çalışma yaşamında hamilelik nedeniyle maruz kaldığı ayrımcılık örnekler üzerinden tartışılacaktır. İş yaşamında hamilelikle ilgili sorunlardan ilkine istihdama katılım sürecinin hemen başında rastlamak mümkündür. İşe alma sürecinin son basamağ muayeneleri esnasında yapılan kan tahlilleri ile kadın adayın hamile olduğunun anlaşılması istihdam kararının işveren tarafından iptaliyle sonuçlanabilmektedir (Regan, 1996). Birçok durumda anneden çok önce 
potansiyel işverenin hamilelik bilgisine ulaşabileceği konusu da düşündürücüdür.

Çalışma yaşamında hamilelik, psikolojik ve fazlasıyla fiziksel bir olgudur. Hamilelikte bitkinlik, mide bulantısı, ağır yük taşıyamama kadının çalışma performansını sinırlayabilmektedir. Mäkelä (2011: 3), hamilelik nedeniyle değişen bedenin örgütlerin toplumsal imajları açısından tuhaf karşılanabildiğinden söz etmektedir. İmajın yanı sıra zaman zaman işyerinde çalışan erkeklerde de bu değişim rahatsızlık uyand1rabilmektedir. Batı toplumlarında işyerinde hamilelik nedeniyle kadınların ayrımcılığa uğraması yaygındır, aynı zamanda çalışan kadınların neredeyse yarısı hamilelik nedeniyle, kendilerine eğitim fırsatının tanınmaması, iş performansının ya da görünüşünün eleştirilmesi, iş tanımının değiştirilmesi gibi somut ayrımcı uygulamalara maruz kalmaktadır (Mäkelä, 2011: 4). Bütün bunların yanında bazı işyerlerinde kadınların hamileliklerini zamanlamalarına ilişkin belgelerin imzalatılması da daha sık karşılaşılan bir uygulamaya dönüşmektedir (Urhan, 2006: 19) .

Kuşkusuz kadının kendi doğurganlığını denetleyebilmesi, onun işgücü piyasası içinde çalışma yaşamını programlayabilmesine yardımcı olmaktadır. Ne var ki bu denetimin boyutu derinleşmekte, kadınla birlikte, devlet ve işveren de denetimde söz sahibi olmaktadır. Çalışma yaşamında tüm yasaklamalara karşın hamilelik işten ç1karma nedenlerinden biri olarak somut örneklerle görülmektedir. İhracata dayalı kalkınma stratejilerinin dünyanın pek çok yerinde ve Türkiye'de geçen yüzyılın son çeyreğinde uygulanmaya başlaması, devlet müdahalelerinin azalarak piyasaların serbestleşmesi, sermayenin uluslararası dolaşıminin hiz kazanmasi, sosyal devlet uygulamalarının neoliberal politikalarla esnetilmesi sürecinin sonunda, dünya üzerinde üretim gelişmiş ülkelerden çevre ülkelere transfer olmuştur. Bu süreçte, ülkelerin gümrük ve diğer mevzuatlarına göre farklılaşan yeni düzenlemelerle kurulan ser- best ticaret bölgelerinde, üretim ihracata dayalı hedefler çerçevesinde gerçekleştirilmeye başlanmıştır. Ucuz işgücü ihtiyacı ile kadın emeğine talep artmıştır. Her ne kadar bu süreçte Türkiye' de kadın istihdamı sınırlı biçimde artış gösterse de (Toksöz, 2011b) dünya genelinde yaşanan bu değişim için emeğin feminizasyonu (Standing, 1989) tabiri kullanılmaya başlanmıştır.

Kadın işgücü talebinin yüksek olduğu serbest bölgelerdeki esneklik anlayışı çalışmamizın konusu olan hamile kadınların maruz kaldığı ayrımcı uygulamaların sıklıkla rastlanıldığ 1 bölgeler olarak ifade edilmektedir. Bu nedenle çalışmada kullanılacak örneklerin büyük çoğunluğu bu bölgelerde yapılan incelemelere dayandırılacaktır.

\section{Serbest Bölgeler}

En kısa ifadesiyle ülkenin siyasi sınırları içinde yer alan gümrüksüz alanlar (Erçakar, 2004) olarak ifade edilen serbest bölgeler, ihracata dayalı ekonomik faaliyetlerin yürütüldüğü, devlet müdahalesinin sinırlı olduğu ekonomik alanlardır. I. Dünya Savaşı sonrası $\mathrm{ABD}^{\prime}$ de faaliyet gösteren serbest bölgeler daha sonra Avrupa'da da görülmeye başlamıştır. Türkiye'de ise XX. yüzyılın başlarından itibaren çeşitli hamleler yapılsa da serbest bölgelerin işlerlik kazanmaları 1985 yılında 3218 Sayılı "Serbest Bölge Kanunu" ile başlamıştır. Mersin ve Antalya'daki ilk serbest bölgelerden sonra farklı yerlerde yirmi bir serbest bölgeden söz edilmektedir (Erçakar, 2004).

Serbest bölgeler, devlet müdahalesinin düşük düzeyde tutulduğu, vergi muafiyetleri nedeniyle firmaları ticari faaliyetlere özendiren ulusal ve uluslararası ekonomik üretim alanlarıdır. Serbest bölge uygulamaları ile her gelişmişlik düzeyindeki ülke küresel ekonomiler içerisinde yer almakta ancak piyasadaki pozisyonu sahip olduğu ekonomik kaynaklar ve bu kaynakları nasıl kullandığına göre değişmektedir. Örneğin azgelişmiş ülkeler, öteden beri ham madde ihracatı ile uluslararası işbölümünde yer alırken, gelişmiş ülkelerin ürün ve teknoloji- 
leri pazarladıkları da bir gerçektir. Uluslararası işbölümü özellikle $X X$. yüzyılın ikinci yarısından sonra değişim göstermiştir. $\mathrm{Bu}$ süreci, küreselleşme ve sermayenin serbest dolaşımı hızlandırmış, azgelişmiş ülkeler bu yeni işbölümü içinde sadece ham madde temininden değil, ucuz işgücü ile üretimden de sorumlu tutulmuştur (Fröbel ve diğ., 1982). İhracata dayalı kalkınma hedeflerini olan Latin Amerika, Güney ve Uzak Doğu Asya, yeni uluslararası işbölümünde ucuz işgücü ile sermaye için cazip görünmektedirler. Fröbel ve diğ. (1982), serbest bölgelerde ücretlerin düşük, çalışma saatlerinin daha fazla, ișten çıkarmanın daha kolay olduğunu belirtmektedir.

Serbest bölgelerdeki ucuz işgücü talebinin karşılanması için kadın emeğinden sıklıkla yararlanıldığ 1 bilinmektedir. Vasıf gerektirmeyen ve uzun çalışma saatleri olan işlerde çalıştırılmak üzere işverenlerin özellikle genç ve bekâr kadınları tercih ettikleri bilinmektedir. Bunun ötesinde bekâr kadınların özel yaşamları bile bu bağlamda soruşturulmaktadır. Özellikle montaj işlerinde, işlemlerin tekdüzeliğine erkeklerden daha kolay uyum sağlamaları nedeniyle serbest bölgelerde yüzde 70 oranında kadın istihdam edilmektedir (Saygıligil, 2007: 17). Bu duruma sıklikla Uzak Doğu ve Latin Amerika'da rastlamak mümkündür. İşverenin işgücü içinde genç ve bekâr kadınları tercih etmesinin en önemli nedeni, bu kadınların üretkenlikleridir; fakat evlendikleri ya da hamile kaldıklarında kolayca işten atılmaktadir (Tickner, 2004: 18).

\section{Maquilalar ve Hamilelik}

Serbest bölgelerin yaygin olduğu Latin Amerika'da bu bölgelerdeki üretim yerlerine maquila ya da maquiladora denmektedir. Sözcüğün kökeni XI. yüzyıla kadar uzanmaktadır. İspanya'daki Arap etkisinin dile yansımasıyla günümüze kadar gelen sözcüğün -maquila- anlamı "değirmencinin payı,

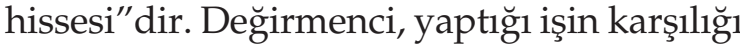
olarak öğüttüğü buğdaydan elde edilen unun bir kısmını almaktadır; ne var ki buğdayın sahibi değildir ${ }^{3}$ Benzer biçimde, Meksika'daki fabrikalarda yarı mamuller ya da mamuller dışarıdan gelmekte, burada montaj1 yapılmakta ve asil firmaya yollanmaktadir. Maquiladora ile maquila arasındaki ilişki dilimizdeki hissedar- hisse ilişkisine benzetilebilir. Maquiladora, fabrikalara verilen isim olmakla birlikte burada çalışan kadınlar için de kullanılmaktadır. Meksika'nın kuzey s1nırında başlayan üretim, daha sonra ülkenin güneyinde de görülmüş ardından Orta Amerika ülkelerinde de aynı isimle kadınlar ve çalışma mekânları tanımlanmıştır (Quisumbing, ve diğ., 2007). Bu çalışmada olası karışıklığ1 önlemek için, üretim mekânını maquila, burada çalışan kadınları ise maquiladora olarak nitelendirilmiştir.

Maquiladoralar ya da kisaca maquilalar, Meksika-ABD sınırındaki yerleşim yerlerinde, yabancı sermayeye ait fabrikalarda yiyecek, tekstil, mobilya, elektronik eşyalar, oyuncak vb. alanlarda ihracata dayalı üretim gerçekleştirmektedir. Montaj işlerinin sıkça görüldüğü maquilalarda $\mathrm{ABD}^{\prime}$ de üretilen parçalar gümrüksüz biçimde Meksika'ya getirilir ve montaj1 tamamland1ktan sonra yeniden ABD'ye gönderilir. 1965 yılında yaygınlaşan bu üretim mekânları, Meksika ekonomisi açısından son derece önemlidir. 2006 yılının Kasım ayı itibarıyla çoğunluğu genç ve kadın, 1.2 milyon kişi maquilalarda istihdam edilmektedir (García ve diğ., 2008: 200). 1994 yllında Meksika, ABD ve Kanada arasında imzalanan Kuzey Amerika Serbest Ticaret Anlaşması'nın (NAFTA) ardından maquilalar ülkenin diğer bölgelerine de yayılmıştır (Hernández, 2000: 213). NAFTA'nın omurgası niteliğindeki bu fabrikalar, önceleri Meksika'nın kuzey sınırında faaliyet göstermişse de daha sonra Yucatan Yarımadası'ndaki yerli Maya kadınları da ucuz işgücü olarak kullanmaya başlamıştır (HuDehart, 2007: 87).

Yapılan bir araştırmada, Tijuana'daki doğum kontrol yöntemleri hakkında bilgi 
sahibi olan maquiladoraların oranı, Meksika'da doğum kontrol yöntemleri hakkında bilgi sahibi olan ulusal kentli nüfusun oranından yüksek çıkmıştır (González, 1996). Yöntemlere dair yüksek bilinç, çalışan kadınların kendi bedenleri üzerinde denetimlerinin güçlü olduğuna işaret ettiği gibi, hamile kalmaları durumunda işten atılma tehlikesi ile burun buruna gelmelerinin de sonucu olabilir. İkinci olasılığın, bu çalışma kapsamında verilen örnekler değerlendirildiğinde, daha yüksek olması muhtemeldir.

1998 Ocak ayında Meksika'da kadın ve emek örgütleri işe girişte hamilelik testi ve hamile kadınların işten atılmalarına karşı bir eylem örgütlemiştir. Başkentte mahkemeye sunulan delillerle, ülkenin kuzey eyaletlerinden Tamaulipas'taki maquilalarda kadınların hamilelik nedeniyle işten çıkarıldıkları ve her ay işyeri hekiminin gözetiminde idrar testi ile kadınların hamile olmadıklarını ispata zorlandıkları iddia edilmiştir (Hernández, 2000: 215). Hernández (2000), bu sorunun yalnızca mavi yakalı maquiladoralar için değil, beyaz ve pembe yakalı kadınlar için de bir sorun teşkil ettiğini belirtmektedir. Yazar, Meksika'da marifetli elleriyle kadınların maquilalarda çalıştı̆̆ 1 durumlarda hamilelik testi uygulamasının ve hamilelik nedeniyle işten çıkarmanın yaygın olduğunu da ileri sürmektedir. Fernández ve Newby (2011: 20) de yaptıkları görüşmelerde benzer bulgulara ulşamışlardır. Görüştükleri kadınlardan biri hamilelik nedeniyle işten çıkarılmış, yeni bir işe de yine hamileliği nedeniyle başvuramayacağını ifade etmiştir. Cravey (1998: 105), maquilalarda kadın ve erkek işçilerin ayrı yatakhanelerde barındıklarını, bu yatakhanelerdeki disiplinin sosyal ve biyolojik yeniden üretimin tüm yönlerini kapsar biçimde işlediğini ve hamileliğin yatakhaneden de kovulma nedeni olduğunu belirtmiştir. Benzer sonuçlar Guatemala maquilalarında da gözlenmektedir. Calfat ve Rivas (2008: 21), ülkede kadın çalışanların 30 yaşına geldiklerinde ya da hamile kaldıklarında işten atılmasının yaygın olduğunu belirtmektedir.
Hamilelik kadınların yalnızca çalışırken karşılaştıkları bir ayrımcılık türü değildir. Henüz işe giriş, mülakat aşamasında karşılarına hamilelik testleri çıkmaktadır. Hamile olmadıklarının delili olarak menstrual döngülerinin başladığı güne göre, işe giriş işlemleri için bekletildikleri de görülmektedir (Bacon, 2004; Hernández, 2000) 1995 yılında İnsan Hakları İzleme Örgütü'nün Meksika'da yürüttüğü araştırmadan kadınların ped vb. temizlik malzemelerinin denetlenmesi gibi utandırıcı, küçük düşürücü uygulamaların varlığ 1 da rapor edilmiştir. Bazı işyerlerinde hamile kadınların daha ağır işlere yönlendirildiği ve işten ayrılmaya zorlandıkları da aynı raporda yer almıştır (Hernández, 2000: 220). İnsan Hakları İzleme Örgütü'nün 1992 yılında Guatemala maquilaları için yaptığı çalışmada da benzer biçimde kadın çalışanların düşük ücret, cinsiyete dayalı ayrımcılık, kötü çalışma koşulları ve temel insan hakları ihlallerine maruz kaldığına dair bulgular elde edilmiştir (Calfat ve Rivas, 2008: 6).

Üstelik hamilelere karşı ayrımcı uygulamalar, yalnızca maquilalarda ya da serbest bölgelerde gerçekleşmemektedir. Finlandiya gibi gelişmiş Avrupa ülkelerinde de hamile kadınlar işyerinde ayrımcılığa maruz kalmaktadırlar. Finlandiya'da işyerinde hamilelik nedeniyle maruz kalınan ayrımcılığa ilişkin yürüttüğü niteliksel çalışmasında Mäkelä (2011: 11-12), görüştüğü kadınlardan birinin ifadesine doğrudan yer vermiştir. Buna göre kadın patronuna ikinci hamileliğini açıkladığında, patronu açık bir şekilde hayal kırıklığına uğradığını çalışanına belirtmiştir. Görüşme yapılan beş kadından üçü dış görünüşlerine dair acımasız yorumlar aldıklarını, hamileliklerini açıladıktan sonra olumsuz tavırla karşılaştıklarını ve toplantılarda herkesin içinde hoş olmayan şakalara maruz kaldıklarını ifade etmişlerdir. Mäkelä'nın (2011) çalışması ayrıca kadın çalışanların hamilelik sürecinde yaşadıkları aşağılanmanın uzun dönemde öz saygılarını da olumsuz yönde etkilediğini göstermiştir.

Meksika'da kadınların istenmeyen hami- 
lelikleri sonlandırmaları yasal yollardan pek mümkün görünmemektedir. Birçok dinde olduğu gibi Katolik Meksika'da da kürtaj katı biçimde sınırlandırılmıştır. Bu katı anlayışın diğer Bu nedenle çalışan kadınların yasadışı, sağlıksız koşullarda kürtaja mecbur kaldıkları ya da sınırı geçip ABD'de kürtaj yaptırdıkları bilinmektedir (Hernández, 2000: 221). Hamilelik nedeniyle maruz kalınan ayrımcılığın, ekonomik sonuçları olduğu gibi ruh ve beden sağlığına ilişkin de ciddi sonuçları olduğu yukarıdaki örneklerden anlaşılmaktadır.

Meksika'da Çin ile rekabet nedeniyle işverenlerce maliyetlerin sınırlandırılması gerekmektedir. Bu nedenle ucuz işgücü önem kazanmaktadır. Genç ve bekâr kadınlar ucuz işgücü olarak değerlendirilirken, hamile kadınlar yüksek maliyetli bulunmaktadır. Maliyetlerin düşürülmesi gündemdeyken, yapılan çalışmalar kadın ve erkek arasında ücret farklılıklarının da arttığını göstermektedir (Charles, 2011). Uluslararası İşçi Sendikalar Konfederasyonu (ITUC) tarafindan hazırlanan raporda Meksika'daki maquilaların rekabet nedeniyle yaşadığ 1 krizden ve hak ihlallerinden söz edilmektedir. Bu çalışma kapsaminda verilen örneklerle örtüșen sonuçlar bu raporda yer almıştır. Rapora göre, örgütlenme hakkının ihlal edildiği bu üretim yerlerinde en önemli problemlerden biri olarak hamile kadınların ișten atılması bir kez daha vurgulanmaktadır. ${ }^{4}$

Kadın çalışanların maruz kaldığı ayrımcılık ve kötü çalışma koşullarına karşı sendikaların yeterli desteği vermediği de belirtilmektedir (Hernández, 2000: 228- 229). Hükümetin sorunlara daha duyarlı olması için NAFTA üyesi üç ülkedeki kadın kuruluşları, sendikal örgütler ortak hareket ederek baskı oluşturmaya çalıșmaktadırlar. Iglesias (2007: 42), Tijuana'daki maquilalarda çalışan kadınların birçoğunun ilkokul mezunu olduğunu belirtmektedir. Meksika eğitim sisteminin ilk ayağ 1 olan ilkokullarda öğretmen emirler veren ve idare eden nitelikleriyle otoritedir. Öğrenciler yumuşak başlı, sabırlı olmayı, öğretmenin yap dediği şeyi sorgulamamayı kısacası itaat etmeyi öğrenmektedirler. Bu deneyim de patronlarla kadın işçiler arasındaki ilişkiye sirayet etmektedir. Kadınların bu zor koşullara karşı çok fazla seslerini yükseltememelerinin tek nedeni elbette aldıkları eğitim değildir. Ekonomik olarak bu işlere ihtiyaç duymaları da çoğu kadını sessizleştirmektedir. İşverenle pazarlık şansları bu anlamda fazla değildir.

Maquilalar ABD-Meksika sınırında başlayıp Orta Amerika'ya yayılmıştır. Bugün, Meksika ile beraber Guatemala, Kolombiya, El Salvador, Honduras, Kosta Rika'da da "boom" olarak tabir edilen patlama yaşanmaktadır. Maquilaların artıșını, kadının ev dışında istihdamının artışı takip etmiştir ancak ev dışında istihdamla kadının özgürleşeceği, yaşam kalitesinin artacağı şeklindeki sav yeniden düşünülmelidir. Guatemala örneği, yerli ve melez yoksul kadınların pek çoğunun istihdam edildiği $m a-$ quilalarda kadının güvencesiz koşullarda ev içindeki konumlarından daha iyi olmadıklarına işaret etmektedir (L'Associació d'Amistat amb el Poble de Guatemala: 72).

\section{İşyerinde Hamile Kalma Yasă̆ı ve Bir Mü- cadele Örneği: Novamed Grevi}

Ağırlıklı olarak Meksika maquilalarından verilen örneklerde, hamile kalmanın yasaklandığı, kadınların periyodik olarak hamile olup olmadıklarının kontrol edildiği, tüm bunlara rağmen hamile kalındığı durumlarda işten atılmaların yaşandığ 1 gerçeği somutlaşmaktadır. Bu örnekler Meksika ile sınırlı değildir. Türkiye'deki serbest bölgelerde de benzer uygulamalara rastlanmaktadir. Antalya Serbest Ticaret Bölgesi'nde faaliyet gösteren Fresenius Medical Care firmasına ait fabrikada çalışanların yüzde 95'i kadındır. Fabrikada, çalışanların sendikaya üye olmama için baskı, kadın çalışanların çocuk sahibi olma haklarına ilişkin ihlaller ve diğer kötü çalıșma koşulları nedeniyle 2006 yılında Petrol-İş bünyesinde örgütlü işçiler greve çıkmıştır. Greve çıkmadan önce 
fabrikada yaşananlar, yukarıda verilen maquila örnekleri ile benzerlik taşımıştır.

Fabrikada oluşturulan hamile kalma takvimleri ile kadın işçilere hamile kalmak için iki aylık süre tanındığı, bu süre içinde hamile kalamadıkları durumlarda adlarının listenin en sonuna yazıldığ 1 çalışanların kendi ifadelerinde yer bulmuștur. Kadın ișçilerden biri evlendiğinde hamile kalma sırası kendisine çabuk gelsin diye henüz nişanlıyken adını listeye yazdırdığından söz etmiştir (Petrol-İş, 2008: 32). Aynı işçi, bazı işçilerin sira kendilerine geldiğinde hamile kalamama ihtimaline karşı önceden doktora gittiklerini de belirtmiştir. Sıra dışında hamile kalan kadın işçilerin ise fabrikada aşağılamalara maruz kaldığından söz edilmektedir. Takvim sırasına uymadan hamile kalan işçilere doğum sonrası yeniden işe alınacakları söylenerek, tazminatları ödenmeden işten ç1karıldıklarından söz edilmektedir (Petrol-İş, 2008: 10). Greve çıkan kadın işçilerle yapılan görüşmelerde, hamile kadınların gece vardiyasında çalışmaları ulusal ve uluslararası düzenlemelerle yasaklanmış olmasına rağmen, hamilelerin burada gece vardiyasında çalıştırıldıkları ifade edilmiştir. Kadınlar bu tür çalıştırmanın yasalara aykırı olduğundan haberdar olmadiklarını ancak grevden sonra fabrikada bu uygulamanın olmadığını da belirtmişlerdir (Akgökçe ve Zırhlı-Kaplan, 2006: 8).

Yukarıda örneklendirilen hamilelik temelli ayrımcı uygulamalar haricinde, evlilik için izin, üretim sırasında yanındaki işçi ile konuşma yasağı, sınırlı tuvalete gitme izni gibi olumsuzluklar da görülmüş, işçilerin sendika çatısında örgütlenme istekleri işverenlerce hoş karşılanmadığında grev, bir sürecin sonunda kaçınılmaz olmuştur. Novamed Grevi, kamuoyunun, akademinin ve uluslararası kadın ve emek örgütlerinin dikkatini çekmiş, geniş bir destek görmüştür. Akademik çalışmalarda da kendine yer bulmuştur (Kümbül-Güler, 2012; Fougner ve Kurtoğlu, 2011; Astarcıoğlu-Bilgiler, 2009; Kıvılcım, 2009; Üstübici, 2009; Yıldırım ve Uçkan, 2007). Novamed örneğinde özellikle görüldüğü üzere, güvencesizleştirmenin bugün vardığı noktada birçok işyerinde, çalışanlara karşı insan onuruna aykırı, kişi hak ve özgürlüklerini ihlal eden muamele, bir çalışma yeri uygulaması ve üretim sürecinin düzenleme şekli olarak kurumsallaşmaktadir (Kivilcım, 2009:228).

Novamed Grevi yurtiçinden ve dişından büyük bir kamuoyu desteği ile 448 gün sonra bitmiştir. Grev henüz devam ederken, firma doğum nedeniyle izinli olan işçiler yerine geçici işler alarak montaj hattında üretimin devamını sağlamış, takvim uygulamasına son vermişlerdir. Kadın dayanışmasının önemli bir örneği olarak emek tarihinde yerini alan bu grev, özellikle serbest bölgelerdeki güvencesiz, emek yoğun üretim içinde kadınların karşı karşıya kaldıkları ayrımcı uygulamaları kamuoyu nezdinde daha görünür olmasını sağlamıştır. Benzer direniş öyküleri, dünyanın pek çok yerinde benzer koşullarda çalışan işçiler tarafından yazılabilir ancak, yoksulluk ve geçim araçlarından mahrum bırakılan insan sayısı arttıkça, özellikle çevre ülkelerde, insan onuruna yakışmayan işlerde ve koşullarda istihdamın arttığ 1 ve bu durumdan etkilenenlerin başında kadınların olduğu görülmektedir (Urhan, 2007: 25).

\section{Sonuç}

Doğurganlık ve hamilelik, kadının işgücü piyasası içindeki yerini etkileyen faktörlerden biridir. XX. yüzyılda, II. Dünya Savaşı'nda erkeklerin seferberlik nedeniyle işgücü piyasasından çekilmeleriyle kadınlar daha fazla oranda ücretli işlerde çalışmaya başlamışlardır. Ancak kadının doğurganlığı, hamilelik dönemi ve ardından doğum, kadını kimi zaman geçici kimi zaman da kalıcı olarak işgücü piyasasından uzaklaştırmaktadır. Doğum kontrol teknolojilerinin XX. yüzyılın ikinci yarısından bu yana hızlı değişimi işgücü piyasası içindeki kadın emeğini de etkilemektedir. Bireysel olarak doğumun ve daha geniş boyutta nüfusun kontrol altına alınması, aynı zamanda işgücünün de kontrolü anlamina gelmektedir. İş- 
gücünün kontrolü ise kisa ve uzun vadeli düşünülmektedir. Hem var olan kadın işgücü hem de gelecek nesillerdeki işgücünün düzenlenmesi bu yolla mümkün olmaktadır.

Çalışma yaşamında kadın, pek çok ayrımcı uygulamaya maruz kalmaktadır. Kadının hamileliği de ayrımcılığın özel bir türü olarak karşımıza çıkmaktadır. Ulusal ve uluslararası koruyucu yasal düzenlemelere rağmen, uygulamada hamilelik nedeniyle ayrımcılık sorununun tümüyle çözülemediği görülmektedir. Kadının doğurganlığı, kadının ev içindeki ve dışındaki çalışmalarını farklı biçimlerde baskı altında tutabilmektedir. Kimi zaman hamile kalması kimi zaman da hamile kalmaması sorunun nedeni olmaktadır. Hamile kalması özellikle çalışma yaşamı içinde sorun teşkil etmektedir.

Hamilelik, kadını geçici sürelerde çalışma yaşamından uzaklaştırmaktadır. Bu uzaklaşmanın fizyolojik ve ekonomik gerekçeleri bulunmaktadır. Ana ve çocuk sağ lığı açısından gerekli görülen bir uzaklaşma fizyolojik nedenlere dayanırken, ekonomik gerekçelerle işgücü piyasasından uzaklaşmasının arkasında kadının hamilelik nedeniyle işverence "pahalı emek" olarak değerlendirmesi etkili olmaktadır. Doğum öncesi ve sonrasında ücretli izin hakkı, doğum sonrası işe başladıktan sonra süt izni hakkı yasalarda düzenlenmiştir. Ancak bu düzenlemelerin işverenler açısından hamile kadın çalıştırmayı maliyetli hale getirmesi, çalışma hayatında hamile kadınların karşılaştıkları sorunun önemli bir boyutuna işaret etmektedir. İşüucü maliyetinin yanında, işyerlerinin toplumsal imajları açısından hamile kadınları görünür kılmak istememeleri, hamileliğe toplumların farklı bakışları da eklenmekte ve hamilelik kadın için işgücü piyasasında büyük sorunların kaynağı olmaktadır. Çalışmada verilen örneklerde görüldüğü gibi, kimi zaman hamile kalmak bile yasaklanmaktadır. Bu ise kadının üreme hakkına yönelik ciddi bir ihlaldir.

Ticaretin serbestleşmesi ve gelişmiş ülkelerde emeğin çalışma koşullarına ilişkin dü- zenlemeler, bu ülkelerdeki üretimi azgelişmiş ve gelişmekte olan ülkelere kaydırmıştır. Kurulan serbest bölgelerde ucuz işgücü ihtiyacı özellikle kadın işgücü aracılığıyla temin edilmektedir. Emeğin feminizasyonu (Standing, 1989) olarak da adlandırılan bu süreçte, kadınlar zor koşullarda çalıştırılmaktadır. Hamile olmadıkları ya da kalmayacakları durumda genç kadınların açıkça üretken ve verimli çalışanlar olduğu düşünülmektedir (Cravey, 1998: 135). Ancak, "vakit nakittir" anlayışlı ile üretim yapılan mekânlarda hamilelik nedeniyle iș performansının düşmesi (Iglesias, 2007: 40) ve ücretli izin hakkının varlığı, ucuz işgücü olarak tercih edilen kadınları işgücü piyasasında dezavantajlı kılmaktadır. Bu dezavantajların başında, hamilelik nedeniyle işyerinde aşağılanma, baskıya maruz kalma ve işten atılma ya da ayrılmaya zorlanmadır.

Düşük ücretlerle, zor çalışma koşullarında çalışan kadınların hamilelik nedeniyle işten atılmaları onların mevcut geçim sıkıntılarını ve yoksulluklarını derinleştirmektedir. $\mathrm{Bu}$ nedenle doğum kontrol teknolojilerinin sunduğu "istediği zaman çocuk yapma fırsatını" çalışan kadınlar kullanamamakta, aksine işverenler bu denetim gücünü kendi ellerinde bulundurmaktadırlar. Örneğin Maquilalarda çalışan kadınlara ilişkin olarak bir üretici, Meksikalı kadınların burada çalışmazlarsa bulaşıkçı olacaklarını, bu fabrikalarda vasıf kazanabildiklerini ifade etmiştir. Ücretlerin düşüklüğüne karşın, kimsenin başına silah dayatılmadığını, kadınların seçim yapabileceklerini ifade etmiștir (Hu-Dehart, 2007: 92). Ancak, gerçekte çalışan kadınlar için doğum kontrolü de bu fabrikalarda çalışmak da bir tercihten öte bir zorunluluktur ve zor koşullarda da olsa çalışmaya devam etmek için bu baskıya çoğu durumda örgütlenme hakkından vazgeçerek razı olmaktadırlar.

Ancak yine de kadınların çalışma yaşamı içinde tümüyle örgütsüz olduklarını söylemek doğru değildir. Serbest bölgelerdeki esneklik anlayışı içinde zor koşullarda çalışmalarına rağmen kadınların mücadele- 
leri umut vericidir. Türkiye emek tarihi ve kadın hareketi açısından önemli bir yeri olduğunu düşündüğümüz Novamed Grevi de "insana yakışır iş" için verdiği mücadele ile bu umudu güçlendirmiştir.

Günümüzde Latin kökenli dillerden İspanyolca'da (laborar/ trabajar) ve Fransizca'da (travailler) çalışmak fiilinin doğurmak, doğum yapmak anlamları olduğu bilinmektedir. İki eylem arasındaki ortaklık anılan kelimenin bir diğer anlamında kendini bulmaktadır: Sancılanmak, sıkıntı çekmek... Çalışma yaşamında kadının sancısı, henüz hamile kalma düşüncesi ile başlamakta ve süreç içinde devam etmektedir. Dominique Méda (2004: 21), Alain Supoit tarafından kaleme alınmış Critique $d u$ droit $d u$ travail (İş Hukukunun Eleştirisi) adlı eserden çalışma ve doğum ilişkisini şu şekilde aktarmıştır:

“Fransızca'da çalışma sözcüğüne atfedilen ilk anlam, kadının çocuk doğururken katlandığı ezadır. Acı ile yaratmanın en üst düzeyde iç içe geçtiği bu doğurma edimini belirtir. Her çalışmada olduğu gibi bu edimde de insan yaratısının sırrı her seferinde yeniden işin içine girer. Çünkü her çalışma, insanın kendi içinde taşıdı ğ 1 güçlerin ve eserlerin benzer bir şekilde sökülüp alındığ́1 yerdir. Ve insan, çocuklarını ve eserlerini dünyaya getirirken yazgisinı tamamlar."

Sonuç olarak, yoksulluk ve ayrımcılığa daha fazla maruz kalmanın kadınlar için bir yazgıya dönüşmesini engelleyecek yeni sosyal politika yaklaşımlarına ve uygulamalarına gereksinim duyulmaktadır. Dünden bugüne kadın haklarına yönelik mücadelelerin tüm kazanımlarına rağmen, uygulamada bu hakların hayata geçirilemeyişinin ardındaki nedenlere de dikkat çekmek gerekir. Bu nedenler arasında devletin karar alıcı organlarının ve işverenlerin ihmal, küçümseme, kaçınma gibi tutum ve davranışları olabileceği hesaba katılarak, ilgili sosyal politikaların oluşturulmasında ayrı bir duyarlılığa gereksinim olduğu açıktır.

\section{Kaynakça}

Akgökçe, N. ve Zırhl1-Kaplan, S. (2006), "Novamed'de Kızlar Grevde: İçerideki Arkadaşları da Yanımıza Çağırıyoruz", Petrol-İş Kadın, Sayı:21,

Akşit, E.E. (2009), "Kısırlık: Olanak ve Tahakküm," Fe Dergi, C.1, S.2, s. 44- 54.

Astarcıoğlu-Bilginer, S. (2009), Feminist Solidarity: Possibility of Feminism in Solidarity Practices?, ODTÜ Sosyal Bilimler Enstitüsü, Ankara: Yayınlanmamış Yüksek Lisans Tezi.

Bacon, D., (2004) The Children of NAFTA, Labor Wars on the U.S./Mexico Border, Berkeley: University of California Press.

Badinter, E. (2011), Kadınlık mı? Annelik mi?, Çev. A. Ekmekci, İstanbul: İletişim Yayınları.

Bailey, M. (2006), "More Power to the Pill: the Impact of Contraceptive Freedom on Women's Life Cycle Labor Supply", The Quarterly Journal of Economics, Vol. 121, No. 1, 289-320

Basalla,G. (1996), Teknolojinin Evrimi, Ankara: TÜBİTAK Yayınları.

Boushey, H. (2008), “' 'Opting Out?' the Effect of Children on Women's Employment in the United States", Feminist Economics, Vol. 14, No. 1, 1-36.

Calfat, G., Rivas, A. (2008) Fragmentation, income, gender and poverty linkages: The case of the Maquila Industry in Guatemala

Charles, A., (2011), "Fairness and Wages in Mexico's Maquiladora Industry: An Empirical Analysis of Labor Demand and the Gender Wage Gap", Review of Social Economy, Vol. 69, No. 1, 1-28.

Cravey, A.J., (1998), Women and Work in Mexico's Maquiladoras, Lanham: Rowman\&Littlefield Publishers. 
Emiroğlu, K. ve Aydın, S. (2003), Antropoloji Sözlüğü, Ankara: Bilim ve Sanat Yayınları.

Erçakar, M.E. (2004), “Serbest Bölgeler: Teorik Yaklaşım”, İş, Güç, Endüstri İlişkileri ve İnsan Kaynakları Dergisi, 6/1.

Ertürk, Ş. (2008), Uluslararası Belgeler ve Avrupa Birliği Direktifleri Işığında Çalışma Hayatımızda Kadın Erkek Eşitliği, Ankara: Belediye-İş Yayınları.

Fernández, L., Newby, A., (2011), "Family Support and Pregnancy Behavior among Women in Two Mexican Border Cities", Frontera Notre, Vol. 22, No. 43, 7-34.

Fougner, T. ve Kurtoğlu, A. (2011), “Transnational Labour Solidarity and Social Movement Unionism: Insights from and beyond aWomenWorkers' Strike in Turkey", British Journal of Industrial Relations, Vol. 49, 353-375.

Fröbel, F., Heinrichs, J., Kreye, O., (1982), Uluslararası Yeni İşbölümü ve Serbest Bölgeler, İstanbul: Belge Yayınları.

García ve diğ., (2008), “Knowledge and Opinions of Emergency Contraceptive Pills Among Female Factory Workers in Tijuana, Mexico", Studies In Family Planning, 39/3, 199-210.

González, M.A. (1996), “La Salud Reproductiva de las Trabajadoras de la Maquiladora de Exportación en Tijuana, Baja California, Diagnóstico y Retos Para las Políticas de Salud", Tijuana, Baja California: Instituto Nacional de Salud Pública, El Colegio de la Frontera Notre y Fundación Mexicana Para la Salud.

Hanmer, J.(1993) "Women and Reproduction' Introducing Women's Studies: Feminist Theory and Practice, (ed) Richardson, D. ve Robinson, V., Hong Kong: The Macmillian Press.
Hernández, G. (2000) “No Mother's Day for Women Workers", No Paradise Yet: the World's Women Face the New Century, (ed.) J. Mirsky, M. Radlett, London: The Panos Institute and Zed Books, 214-232.

Hu-Dehart, E.,(2007), “Surviving Globalization: Immigrant Women Workers in Late Capitalist America", Women's Labor in the Global Economy, (ed.) S. Harley, New Brunswick:Rutgers University Press, 85-102.

Iglesias, N. (2007) Beautiful Floweres of the Maquiladora, Austin: University of Texas.

Kıvılcım, Z., (2009) “İnsan Hakları ve Karşı Hegemonya", Gazi Üniversitesi Hukuk Fakültesi Dergisi, XIII :1-2, 217-240.

Kümbül-Güler, B. (2012) "Psiko-Sosyal Boyutuyla Grev", Çalışma ve Toplum, S. 32, 113-146.

L'Associació d'Amistat amb el Poble de Guatemala, (tarihsiz), Economia Global: El Caso de Guatemala, http:/ / www.aapguatemala.org/05_brigades/descarregues/dossier2_economia.pdf (03.03.2012).

MacKenzie, D. ve Wajcman, J. (1985), The Social Shaping of Technology, Buckingham: Open University Press.

Mäkelä, L. (2011), “A Narrative Approach to Pregnancy-related Discrimination and Leader-follower Relationships", Gender, Work and Organization, Blackwell Publishing, 1-22.

Méda, D. (2004), Emek: Kaybolma Yolunda Bir Değer mi?, İstanbul: İletişim Yayınlar1. 
Mohapatra, S. ve Roy, S. (2010) “Work and Fertility Linkage in Women: A Study in Bhubaneswar City", Zagreb International Review of Economics \& Business, Vol. 13, No. 2, 39-53.

Morsy, S. (1997), "Biotechnology and the Taming of Women's Bodies", Processes Lives: Gender and Technology in Everyday Life, (ed) Terry, J. ve Calvert, M., New York: Routledge, 165-173.

Özşuca, Ş. T. (2003), Esneklik Güvenlik İkileminde Türkiye Emek Piyasası, Ankara: İmaj Yayınevi.

Petrol-İş, (2008) Novamed Grevi, Küresel Sermayeye Karşı Küresel Kadın Dayanışması, Novamed İşçilerinin 448 Günlük Direnişlerinin Yankıları, İstanbul: Burhan Ofset.

Quisumbing, A.R., Hallman, K., Ruel, M.T. (2007), "Maquiladoras and Market Mamas: Women's Work and Childcare in Guatemala City and Accra", Journal of Development Studies, Vol. 43, No. 3, 420-455.

Regan, P.M. (1996), "Genetic Testing and Workplace Surveillance", (ed.) D. Lyon ve E. Zureik, Computers, Surveillance and Privacy, Minneapolis: University of Minnesota Press, 21-46.

Saygılıgil, F. (2007) "Serbest Bölge: Yasak Bölge", Petrol-İss Kadın, Sayı: 25, 16-17.

Savc1, İ. (1999), “Toplumsal Cinsiyet ve Teknoloji", SBF Dergisi, 54/1, 123-142.

Standing, G., (1989), "Global Feminisation Through Exible Labour", World Development, Vol. 17, No.7,

Tickner, J. A. (2004), The Gendered Frontiers of Globalization, Globalizations, Vol. 1, No. 1, 15-23

Toksöz, G. (2011a), Kalkınmada Kadın Emeği, İstanbul: Varlık Yayınları.
Toksöz, G. (2011b), “Women's Employment in Turkey in the Light of Different Trajectories in Development-Different Patterns in Women's Employment," Fe Dergi 3/ 2, 19-32.

Urhan, B. (2007), “Nasıl Olursa Olsun İş (mi)?", Petrol-İş Kadın, Sayı:25, 24-25.

Urhan, B. (2006), "Kadınlar 'Kendi İşine'?", Petrol-İş Kadın, Sayı:23, 18-19.

Ustubici, A. (2009) "Export-Processing Zones and Gendering the Resistance: "Women's Strike" in Antalya Free Zone in Turkey", London School of Economics, Gender Institute, New Working Paper Series, Issue 24.

Yıldırım, E. ve Uçkan, B. (2007) “Union Avoidance in Turkey: the State and Employers vs.Unions",

http:/ / www.ilera-online.org/15thworldcongress/files/papers/Track_2/Thur_ W5_UCKAN.pdf (07.03.2012).

Yıldız, G.B. (2008), İşverenin Eşit İşlem Yapma Borcu, Ankara: Yetkin Yayınlari. 
